\title{
Istitutioni Harmoniche Gioseffa Zarlina in antična glasbena teorija
}

Gioseffo Zarlino, po mnenju mnogih osrednji in najvplivnejši italijanski glasbeni teoretik 16. stoletja, je na začetku traktata Istitutioni harmoniche (Temelji harmonike) glasbo predstavil kot matematično znanost. Prepričan je bil, da mora pravi muzik poznati tudi spekulativno plat glasbe, saj je ravno poglobljeno teoretsko znanje tisti temelj, iz katerega izhaja vsakršno glasbenopraktično udejstvovanje. V tem svojem prepričanju se je v humanističnem duhu v veliki meri navezoval na poglede antičnih glasbenih teoretikov, ki jih je prevzemal in na njih gradil vsebino svojega traktata. Na ta način se njegova razprava o glasbi kaže kot prvovrstni vir za preučevanje razumevanja in prevzemanja antičnih glasbenih teoremov v renesančno glasbeno teorijo: Zarlino ni bil teoretik, ki bi antično izročilo le povzel, pač pa ga je interpretiral, razumel in v Istitutioni predstavil z ozirom na glasbo svojega časa.

$\mathrm{V}$ povezavi z nakazano problematiko zasleduje razprava predvsem tri cilje:

(1) Umestiti Zarlina in Istitutioni v zgodovinski kontekst: pokazati, da je traktat v taki obliki in s tako vsebino lahko nastal le znotraj specifičnega zgodovinskega prostora in časa, v renesančni Italiji 16. stoletja.

(2) Predstaviti, kako se je v danem okolju in času kot humanistični učenjak oblikoval Zarlino: ugotoviti, na kakšen način in v kolikšni meri je spoznaval antično (glasbenoteoretsko) izročilo.

(3) V ospredje postaviti vsebino Istitutioni in različne vidike njenih povezav z antično glasbeno teorijo.

Izhajajoč iz zastavljenih ciljev je vsebina disertacije razdeljena na tri dele. V prvem so orisane značilne kulturnozgodovinske okoliščine, v katerih so nastale Istitutioni. Za razumevanje Zarlinovih glasbenoteoretskih zamisli je gotovo ključnega pomena zavedanje, da ni bil izoliran posameznik in da je bil kot italijanski učenjak v središču dogajanja: humanistična miselnost in v njenem okviru novi pogledi na antiko in antično izročilo so se najprej pojavili prav v italijanskih mestih; med slednjimi so se kot eno izmed najpomembnejših že v visokem srednjem veku uveljavile Benetke. Te so spričo razvejane pomorske trgovine, gospodarske in finančne blaginje ter relativne politične stabilnosti privlačile mnoge tujce, med katerimi so bili tudi številni učenjaki in umetniki. Ti so s seboj prinesli mnoge sveže zamisli, ki so pomembno pripomogle, da je mesto, posebno po skokovitem vzponu tiskarske dejavnosti v drugi polovici 15. stoletja, postalo eno najpomembnejših sedišč renesančne kulture. Od začetka štiridesetih let 16. stoletja je tu živel in deloval tudi Zarlino.

V drugem delu disertacije je ob pregledu Zarlinovega življenja podrobno predstavljen njegov študij antike in spoznavanje antičnih virov. Prek študija in kasnejšega 
glasbenega in neglasbenega delovanja, posebno prek poglobljenih razprav z drugimi učenjaki časa, je Zarlino prevzemal in hkrati pomembno sooblikoval renesančno humanistično paradigmo navezovanja na antiko. Ključnega pomena za preučevanje antičnega izročila je bila razpoložljivost virov, najprej latinskih in nato od konca 15 . stoletja dalje še grških. Kot pomemben beneški učenjak in viden član Accademie Veneziane je imel Zarlino spričo Bessarionovega darila mestu na voljo vse pomembnejše grške spise o glasbi: način njegovega dojemanja in razumevanje antike in antične glasbene teorije v Istitutioni je nedvomno tudi posledica širokega dostopa do izvirnikov in možnosti za njihovo preučevanje.

Tretji del disertacije izhaja iz traktata samega: ob obravnavi posameznih Zarlinovih teoremov je prikazano, v kolikšni meri, na kakšen način in s kakšnim namenom je v njem obravnavana in prevzeta antična glasbena teorija. V skladu s pogledi antičnih teoretikov je glasba v začetku Istitutioni postavljena kot eksaktna matematična znanost, tesno povezana z ostalimi kvadrivialnimi disciplinami. Zarlino trdi, da se prek nje dostopa do najvišje resnice, saj je v obliki harmoničnih razmerij prisotna povsod: vse, kar obstaja, je harmonično (glasbeno) urejeno. V nadaljevanju se v traktatu razpravlja le o dejanski, zveneči glasbi; najprej se utemeljuje tonski sistem, znotraj katerega more obstajati. Izpostavljeno je prepričanje, da je bila antična glasba drugačna od sodobne, zaradi česar je bil tudi njen tonski sistem nujno drugačen. Ta sodobni glasbi ni več zadosten, potrebno ga je spremeniti, razširiti in prilagoditi. Tako Zarlino namesto konsonanc, opisanih z razmerji prvih štirih števil (quaternario), uvede sistem, utemeljen na številu šest (numero senario), v katerega so vključene tudi lepo zveneče terce in sekste. Iz njega je nadalje izpeljan eden jedrnih konceptov Zarlinove glasbene teorije, zveneče število (numero sonoro), ki je postavljeno za predmet muzikovega preučevanja: $\mathrm{v}$ kompozicijah je dovoljeno uporabljati le intervale, katerih termine razmerij najdemo med zvenečimi števili, izpeljanimi iz števila šest in njegovih delov. Izgradnja tonskega sistema se zaključi z razpravo o uglasitvi: Zarlino dokazuje, da se v sočasni vokalni glasbi rabi Ptolemajeva sintonična diatonična oz. čista uglasitev, medtem ko mora biti uglasitev v instrumentalni glasbi temperirana.

Teoretičnim poglavjem sledi obravnava glasbenopraktičnih tem: spekulativni premisleki in zgrajeni tonski sistem so v tretji in četrti knjigi povezani z naukom o kontrapunktu in z razpravo o modusih. Na ta način se antična glasbenoteoretska tradicija $\mathrm{V}$ Istitutioni $\mathrm{v}$ veliki meri kaže kot model in sredstvo za dosego ozko določenega cilja: izgradnjo tonskega sistema, znotraj katerega poteka glasbena praksa časa in znotraj katerega je po Zarlinovem prepričanju možen in od njega odvisen v spisu predstavljeni nauk o kontrapunktu.

Prevzemanje antičnih kanonov je v renesansi postalo postulat. Toda misleci časa jih niso prevzemali dosledno, temveč so jih v prvi vrsti postavljali za vzor in izhodiščni model, ki ga je moč prilagoditi realnosti lastnega časa. V tem smislu so renesančni znanstveniki antične zamisli preučevali, kritično pretresali, predrugačili, nadgradili in tako prišli do novih spoznanj ter postavljali nove sisteme. Na enak način je poglede antičnih glasbenih teoretikov prevzemal Zarlino: V stari Grčiji je nastal osnovni kanon glasbenoteoretskih toposov, ki so ga poznoantični avtorji in posebej Boetij prenesli v srednji vek. Zarlino je vsebino ključnih antičnih glasbenoteoretskih spisov, na katere 
se sklicuje v Istitutioni, dobro poznal in iz nje v svojih premislekih izhajal. Toda ni je prevzemal dosledno in nespremenjene, temveč jo je (morda najjasneje izmed vseh teoretikov časa) redefiniral: prosto jo je komentiral, interpretiral, širil, krčil, predvsem pa prilagodil glasbeni praksi svojega časa in na ta način postavil glasbenoteoretski sistem, s katerim je opisal sodobno glasbo.

Obranjeno 24. aprila 2017 na Filozofski fakulteti Univerze v Ljubljani. 